\title{
Economic Roots of Political Conflict: The Case of Sri Lanka
}

\author{
Sirimal Abeyratne \\ Department of Economics, \\ University of Colombo \\ (Email: econ@cmb.ac.lk) \\ Visiting Fellow \\ Division of Economics, Australian National University
}

\begin{abstract}
Escalation of political conflict in many developing countries and their impact on economic development has been a topical issue in recent development literature. The overwhelming emphasis on 'ethnic conflicts' in this literature has, however, precluded looking at political conflict in the wider context of the development process, going beyond the ethnic dimension. In particular, because of the preoccupation with the ethnic roots as the prime source of these conflicts, reverse causation running from economic policy to political conflict has been virtually ignored in the debate. The purpose of this paper is to redress this gap through an in-depth case study of the 'twin political conflict' in Sri Lanka-the Tamil separatist war in the North and the Sinhala youth uprising in the South —with emphasis on its economic roots. The findings suggest that fundamental contradictions in the national development policy throughout the post independence era were in the heart of the country's twin political conflict.
\end{abstract}

JEL Classification: $\mathrm{B} 0, \mathrm{O} 1, \mathrm{O} 53$

Keywords: political conflict, ethnic conflict,, Sri Lanka 


\section{Economic Roots of Political Conflict: The Case of Sri Lanka*}

\section{Introduction}

During the latter half of the twentieth century an increasing number of developing countries have been exposed to internal political conflict and consequent civil war (Abeyratne 1998, Bardhan 1997, Gurr 1993). ${ }^{1}$ The developing countries have also been experimenting with different policy regimes and planning exercises to achieve economic development. Consequently, the relationship between political conflict and economic development has received considerable attention in the recent development literature.

There are two obvious limitations in the fledgling literature on this subject. Firstly, in most studies, direction of causation has been depicted as running from political conflict to economic development, ignoring the possibility that a particular pattern of the development process itself can lead to political conflict (Bardhan 1997, Stewart et. al. 2001, Stewart and O'Sullivan 1999). Secondly, the few available studies on economic causes of political conflict have solely focused on a particular type of political conflict, namely ethnic conflict (Collier 2001, Collier and Hoeffler 1998, Easterly and Levine 1997, Lewis 1985). This might be a result of the considerable recent attention paid in international forums on discrimination against ethnic minorities all over the world. (Gurr 1993). What ever the reason may be, this narrow focus has led to a misleading inference that all forms of civil war in the developing world have been resulted from ethnic conflict. In reality root causes of political conflict, including those of ethnic conflict, usually run well beyond ethnic differences. Moreover, in a political conflict that ex ante looks like an

\footnotetext{
* An earlier version of this paper was presented at the staff seminars of the Economic Division, Australian National University in Canberra and the School of Economics, the University of Queensland in Brisbane. Author wishes to thank Prema-chandra Athukorala and the participants at these two seminars and for their valuable comments. A special word of thank is due to the Department of Economics, Research School of Pacific and Asian Studies, ANU for financial support.

${ }^{1}$ The term 'political conflict' is used here to refer to either active or potential use of collective violence, including civil war-the deliberate destruction of persons and property by people acting together-in order to achieve specified political objectives (Rule 1988). The terms 'political conflict' and 'civil war' are used interchangeably in the paper.
} 
ethnic conflict, ethnicity could well be only a mobilization device rather than the root cause.

The purpose of this paper is to redress these gaps in the current debate on political conflict through a case study of the Sri Lankan experience in the recent past. Sri Lanka, a country that was seen at the time of independence from Britain in 1948 as a first potential case of development success in the third world, surprisingly transformed subsequently into a state of political conflict and consequent armed struggles. Sri Lanka's political conflict, developed since the 1970s, has two major facets. One is the Tamil separatist movement, which is widely known to be between the majority Sinhala and the minority Tamil communities ('ethnic conflict'). The other is the militant movement of the Sinhala community, which erupted twice into armed struggles with the aim of changing the existing political regime. Due to the concurrent escalation of the two facets of the political conflict, it is rather a 'twin political conflict' in which mere the ethnic conflict cannot be separated analytically.

A great majority of the analyses on the issue has, however, drawn attention overwhelmingly to the Tamil separatist movement, ignoring the importance of the two facets of the overall political conflict. ' ${ }^{2}$ More recently, international attention on Sri Lanka has focussed ...on its intractable and brutal civil war between the majority Sinhalese and the minority Tamils' (Stewart and O'Sullivan 1999: 374). The focus of the many analyses on the ethnic conflict has inevitably led to a misleading impression that Sri Lanka's political conflict is merely an 'ethnic issue' and that it has to be analyzed in the context of ethnic disparities of the country. The approach naturally precludes the possibility of analyzing the issue from a wider perspective beyond the ethnic character. This paper shows that the contradictions of the development process, resulted from the national development policy in Sri Lanka, created a fertile ground for the emergence of its twin political conflict and the consequent civil war. Its Tamil separatist movement, however, gained momentum and continuity by exploiting the ethnic character.

\footnotetext{
2 The ethnic conflict of Sri Lanka has been widely studied from different social science perspectives. For example, see Abeysekera and Gunasinghe (1987), Jayawardena (1984), Spencer (1990), SSA (1985), Tambiah (1986) and Wilson (1988). Among the few studies available on the youth militant movement of the Sinhala community, for example, see Hettige (1992), Moore (1993) and Obeyesekere (1974).
} 
The paper is organized in four sections. First, we explore the development prospects of Sri Lanka, which were constituted by its favourbale initial conditions at the time of its independence and, contrary to that the escalation of political conflict in two facets. In exploring the economic roots of the 'twin political conflict', secondly we focus on the contradictions in the post independence development process with emphasis on the underlying policy errors. Thirdly, we examine the social exclusion of emerging new generation-the youth, brought up in a welfare democracy-in the development process in creating a fertile ground for the formation of the political conflict. Finally, in the concluding section we summarize the lessons from the Sri Lankan experience and point to the factors that should receive due cons ideration in designing long-run development strategy.

\section{Development prospects and political conflict}

The economy of Sri Lanka at independence in 1948 was much more prosperous compared to most of its Asian neighbours. The colonial inheritance included a high human development standard, well-developed infrastructure, a well-functioned judiciary and a democratic political system of the Westminster type. Due to the prosperous primary export crops developed during the colonial times, ${ }^{3}$ Sri Lanka's '...national income per head is, up till now, one of the highest in Asia' (Robinson 1959: 40). Along with high income, the country's achievements in terms of consumption, health and education was 'excellent'. Sri Lanka's achievements in human development were exceptional among developing countries and were comparable with those of developed countries (Bhalla, 1988, Isenman 1980, Sen 1983). The main development problem at the time was not that of raising living standards of people, but of maintaining it against rapidly growing population. Sir John Hicks who visited Colombo as an economic advisor to the Sri Lankan government in the late 1950s wrote: 'If it were not for the population pressure, the urge for development [in Sri Lanka] might not be so very great; for there is not at the moment a crushing problem of poverty and malnutrition such as there is in neighbouring countries' (Hicks 1959: 9).

\footnotetext{
3 Plantation agriculture, which had become the backbone of the Sri Lankan economy, accounted for $88 \%$ of export earnings, $37 \%$ of GDP and, $27 \%$ of employment at the time of independence (Snodgrass 1966). The economic prosperity based on plantation agriculture improved further due to its favourable world market conditions of primary exports of the country, particularly tea and rubber, in the first half of the 1950s.
} 
The country also inherited a highly competitive pluralistic political system, which was generally considered an outstanding model $f$ third world democracy (Jupp 1978, Kearny 1973, Wilson 1979). This was characterized by regular general elections, based on universal franchise, ${ }^{4}$ to select the governments and, a high degree of popular political participation in the decision making process. In referring to the favourable initial conditions as well as the peaceful transfer of power from colonial rule to independence, Snodgrass (1999: 89) questioned: 'what more could a newly independent nation want?' Many viewed Sri Lanka as a first potential case in development success among the newly independent nations at the time.

A good regional comparator for assessing Sri Lanka's post-independence economic performance is Malaysia, a country at independence (in 1957) shared much in common with Sri Lanka in terms of its economic, social and cultural factors, including ethnic composition and the inequalities between ethnic groups (Bruton 1992). It exhibited the symptoms of potential political conflict, particularly between the majority Malay and the minority Chinese communities by the end of the 1960s. The affirmative actions of the Malay government in the 1970s were also based on economic disparities between ethnic groups and aimed at upgrading the economic capabilities of the majority Malay community. Yet, Malaysia was able to avoid the possibilities of its potential ethnic conflict and achieved a sustainable growth momentum along with promoting employment and equity (Athukorala 2001, Bruton 1992). Sri Lanka failed in lessening its potential for political conflict, though Malaysia succeeded. The escalation of civil war itself imposed massive costs on the economy and retarded the potential economic development of Sri Lanka (Arunatilake et. al. 2001, Richardson and Samarasinghe 1991). An important question is, therefore, why did Sri Lanka gradually deteriorate into a state of large-scale political conflict and the consequent civil war, when a country like Malaysia achieved rapid economic development while maintaining with a similar pluralistic society.

\section{Escalation of political conflict}

From the 1970s the democratic political system and the territorial integrity of Sri Lanka came under increasing threat of growing political conflict concurrently in two facets. In 1971, there emerged an insurrection, organized by the youth of the Sinhala community to capture state power. The Sinhala community is the main ethnic group of the country

\footnotetext{
${ }^{4}$ Prior to independence from Britain, Sri Lanka obtained universal franchise as early as 1931. Even before that, since the early 1900s Sri Lankans had begun to acquire decision-making powers in the State Council the legislature. In 1921, members elected by the Sri Lankans plus appointees outnumbered the British
} 
accounting for nearly three-fourth of the total population. The Sinhala community is concentrated largely in the Southern part of the country. The militant organization of the Sinhala youth, known as the JVP (Janatha Vimukthi Peramuna, which means People's Liberation Front), after its first aborted attempt, dissolved temporally. The JVP arose again by the early 1980s and made their second attempt launching an armed struggle since 1986 to capture state power. The large-scale violence spread over the Southern parts of the country and lasted for a period of four years till 1989. But the JVP has continued to remain as an important force in the political scene.

The militant youth movements of the Tamil community were also formed in the 1970s. The Tamil community is the country's second largest ethnic group, which accounts for $12.8 \%$ of the total population. ${ }^{5}$ They are concentrated mainly in the Northern part of the country. ${ }^{6}$ The Tamil militant movements consisted of the Liberation Tigers of Tamil Eelam (LTTE) and some other groups. These groups started their armed struggle against the state with sporadic political assassinations in the second half of the 1970s. They also gradually entered into a guerrilla war, aimed at carving out a separate Tamil state in Sri Lanka, and launched their full-scaled armed war in 1983. The outbreak of two armed conflicts simultaneously in the second half of the 1980s was marked by a complete break down of the rule in the country and the normalcy in civil society. The government succeeded in repressing the armed struggle of the Sinhala youth militarily by the end of 1989, though the JVP continued to remain in the political scene. But the Tamil separatist war between the LTTE and the government forces continued to date. ${ }^{7}$

Many of the analysts have approached these two uprisings, guided by different political objectives, separately (Abeysekera and Gunasinghe 1987, Hettige 1992, Moore

members, while three years later in 1924, elected members alone were the majority in the State Council. (Oliver 1957)

${ }^{5}$ This figure comes from the population census conducted in 1981. Although the enumeration of population was stopped after 1981 due to the civil war in the Northern and Eastern provinces, it was carried out again in 2001.

${ }^{6}$ In the population census of Sri Lanka, the total Tamil community is classified into two groups. The group that we refer to here is the 'Sri Lanka Tamil' community in the North. The other is the 'Indian Tamils', which were brought by the British from India as plantation workers and were concentrated largely in the plantation areas in the central part of the country. The Indian Tamil community accounts for 5.6\% of the total population. 
1993, Spencer 1990, Tambiah 1986, Wilson 1988). But they could be analyzed in the same historical context as they reveal important historical connections (Kloos 1993). The twin political conflict is an emergence of ambitious radical youth from both Sinhala and Tamil communities simultaneously against the established traditional political system of the country, represented also by both communities. Particularly, they emerged in an economic background where the economy continued to fail in meeting the aspirations of youth.

The political parties of Sinhala and Tamil communities characterized the traditional political establishments of the country. All major political parties were multi ethnic parties, as they included members of the minority ethnic groups in their leaderships. However, there were also minor political parties based on the country's ethnic divisions. They also participated in the decision making process of the country being either in coalition governments or in opposition. Within this complex system of post independence governance of the country, the ethnic divisions paved the way for conflict in political interests between the Sinhala and the Tamil communities (Abeyratne 1998, Kloos 1993). 'Ethnic antagonisms were present, particularly between the Sinhalese nationalists who dreamt of a Sinhalese Sri Lanka and the minority Tamils, who feared that British rule would be replaced by Sinhalese rule' (Athukorala and Jayasuriya 1994: 6). Therefore, the conflict in political interests between the two communities emerged as far back as the preindependent times and was represented in the post-independent competition for political power.

As neither the Sinhala nor the Tamil were homogeneous communities in terms of political, social, cultural and economic factors, there was a conflict in interests between different segments in each community (Abeyratne 1998, Kloos 1993). Politically, the emergence of radical youth from both communities in the 1970s against the established traditional political system was a clear demarcation of different political interests within the communities. The social, economic and cultural factors that resulted in divisions within each community were also important in identifying the demarcation between those who represented the traditional political establishments and those who represented the

\footnotetext{
${ }^{7}$ After 1987 among a number of Tamil militant groups only the LTTE carried out the separatist war against the state. Some of the other groups were destroyed by the LTTE while the rest joined the parliamentary democratic process of the country.
} 
radical youth movements (Kloos 1993, Moore 1993). The radical youth who represented both the Sinhala and the Tamil militant movements were '...far more nationalist than their majorities' (Kloos 1993: 13). These youth militant movements from both communities were formed against the traditional political establishment represented by their own communities. Therefore, the political conflict developed in Sri Lanka is not only between the communities, but also within the communities. Although part of the conflict has been characterized as an 'ethnic conflict', it also does not mean that there is conflict between the two communities either at macro level or at individual level. Given these fundamental characteristics of the two militant movements, the political conflict in Sri Lanka appears to be rather a 'twin conflict', which requires considerations beyond the simple ethnic factors, as they shared historical commonalties.

\section{Contradictions in development}

In the post independence development process of Sri Lanka, divergent social groups and isolated regions, which were unified politically and economically, were brought up within a state of 'welfare democracy'. This process has been characterized by an increasing social demand for resources and opportunities required for upward social mobility of individuals, social groups and regions. In contrast, the economy has failed in generating adequately the resources and opportunities demanded by the society. The inadequate expansion of economic capacity to meet the increasing social demand created important contradictions in the historical development process of Sri Lanka. The gradual exclusion of individuals, social groups as well as regions from the mainstream development process was an inevitable outcome of these contradictions in development.

\section{Expansion of the welfare system}

The strong claim for social welfare has been an important element of the historical development process in Sri Lanka. The country started to expand its welfare programmes since the 1940s largely as a response to the political challenge of the left wing political parties, which constituted the main opposition to the conservatives at the time (Athukorala and Jayasuriya 1994). The initial advantageous position of the economy, which was taken as granted and permanent state of the country, gave the necessary impetus and financial 
strength to expand the social welfare system. As a result, the successive post independent governments were able to maintain an exceptional type of a 'welfare state', which was exceptional when considered in relation to most of the other developing and even fast growing countries in the third world.

The major welfare programmes included, among many others, free health care (both curative and preventive) and free education from primary to university level (including free mid-day meal and milk at school, later free uniforms and textbooks) covering the entire country. Moreover, state subsidies on staple food-rice, which sometimes was provided free of charge, and on other essential consumer goods and services, covering the whole population were important components of the system.

\section{Table 1}

Human Development Record of Sri Lanka 1960 and 1998

\begin{tabular}{lrr}
\hline Indicators & $\mathbf{1 9 6 0}$ & $\mathbf{1 9 9 8}$ \\
\hline Infant mortality rate (per 1000) & 71 & 16 \\
Life expectancy at birth (years) & 62 & 74 \\
Primary school enrolment (\%) & 95 & 100 \\
Adult literacy rate (\%) & 75 & 91 \\
Human development index & 0.48 & 0.73 \\
\hline
\end{tabular}

Source: World Bank, World Development Report(annual issues) and UNDP, Human Development Report (annual issues)

The total recurrent and capital expenditure on welfare services accounted for over one-fourth of total government expenditure in the 1950s and the 1960s, and has subsequently escalated further, except during a period of an interlude in the 1980s (Abeyratne 2000). By assessing Sri Lanka's achievements in social welfare development, Sen (1988: 553-554) wrote: 'Several innovative changes were introduced into social welfare programs in Sri Lanka in the 1940s, and the momentum of fast expansion was clearly present through the $1950 \mathrm{~s} . .$. As it happens this was also a period of sharp increases in life expectancy and of big declines in mortality rates...' The achievements in human development, as shown in Table 1, stand as a distinct feature of the country's economic development. 
Table 2

Increase in Population 1950-95

\begin{tabular}{lrrrr}
\hline Year & $\begin{array}{r}\text { Population } \\
\text { (millions) }\end{array}$ & $\begin{array}{r}\text { Birth rate } \\
\text { per 1000 }\end{array}$ & $\begin{array}{r}\text { Death rate } \\
\text { per 1000 }\end{array}$ & $\begin{array}{r}\text { Population } \\
\text { growth (\%) }\end{array}$ \\
\hline 1950 & 7.5 & 40.5 & 12.6 & 3.3 \\
1960 & 9.9 & 36.6 & 8.6 & 2.8 \\
1970 & 12.5 & 29.4 & 7.5 & 2.1 \\
1980 & 14.7 & 28.4 & 6.2 & 1.9 \\
1990 & 17.0 & 20.1 & 5.8 & 1.1 \\
1999 & 19.0 & 17.3 & 6.0 & 1.4 \\
\hline Source: CBSL (2000) & & &
\end{tabular}

The extensive welfare system also resulted in a rapid growth of the country's population, which almost doubled during the period of 30 years from 1950 to 1980 (Table 2). This was a product of 'the primitive birth rate combined with the modern death rate', the latter reflecting the effects of government actions rather than 'natural' economic advancement (Robinson 1959: 39). The growth of younger generation was faster than the population growth; as a result, about half of the total population belonged to the age group below 20 years, and more than one -fourth to the age group below 10 years during the period of 1950s-1970s (Abeyratne 1998). This created a pressure on the economy and on the welfare state and, subsequently exacerbated the expansion of social demand for economic resources and opportunities.

The welfare system has, however, expanded enough covering the whole population and the entire country to look after the expanding young generation, through improvements in nutrition, health and education. The youth who were brought up within an extensive welfare system no longer remained in their traditional family based economic system and ceased to rely on their birth status as a source of identity (Hettige 1992). The capacity of the state should have expanded to meet the increasing social demand of these youth for economic resources and opportunities for their upward social mobility. This depended on an adequate expansion of the economic potentials through rapid economic growth, in which the country appears to have failed for decades. 


\section{Viability of the welfare state}

The country's extensive welfare system coupled with a high degree of political liberalism created a welfare-depended society at the expense of creating a conducive setting for economic growth. By the 1960s there were clear signs that Sri Lanka has been living far beyond its means (ILO 1971). Although in academic and policy discussions, Sri Lanka was quoted as an exceptional and a success case of achieving redistributive justice human development among developing countries, the critical issue of its sustainability has rarely drawn the attention in these discussions. According to Lakshman (1975: 65) '...the viability of any redistributive strategy is likely, in the long-run, to be seriously undermined by economic stagnation'. In the absence of a growth momentum, the sustainability of the welfare state gradually came under increasing threat in two fronts:

- First, the maintenance of the welfare system itself required a continuous flow of resources to finance it. The financial resources should be generated out of the expansion of the economy. This fundamental requirement appears to have been ignored in Sri Lanka. As pointed out earlier, the expansion of the welfare system was based on not the realities but the contemporary economic prosperity prevalent at the time of independence.

- Secondly, the state had to face the massive social demand that emanated from an extensive welfare system. People who were brought up within the welfare system had improved capabilities and higher social expectations. The capabilities needed to be utilized and the expectations to be satisfied in the development process by a corresponding expansion of the economy.

The above requirements point to an important contradiction in the post independence development history of Sri Lanka. The expansion of the social welfare system was based not on a sustained growth momentum of the economy but on the historically accumulated resources, which formed its initial economic conditions. As Snodgrass (1999: 89) aptly put it, 'whatever a reasonable assessment at the time may have been, succeeding decades have revealed Sri Lanka as an undistinguished economic performer among the developing nations of Asia and the world'. The Sri Lankan economy, which once promised to be the 'best bet in Asia', continued to lag behind the 
growing economies in Asia, which were at comparable stages at the time but surpassed Sri Lanka soon (Abeyratne 2000, Athukorala and Jayasuriya 1994, Lakshman 1997). Table 3 shows a comparison of Sri Lanka with some other Asian countries in terms of per capita GNP relative to the USA, adjusted for the Purchasing Power Parity.

In 1955, Sri Lanka's per capita income was greater than that of other major Asian countries, except Malaysia ${ }^{8}$ (Table 3). South Korea and Thailand continued to lag behind Sri Lanka in terms of per capita income even by 1960. A striking feature of the Sri Lankan economic perfor mance is that its relative per capita income even in 1995 is not much different from what it had 40 years ago in 1955. Sri Lanka was able to achieve a moderate growth performance following trade liberalization after 1977, but surprisingly in the midst of growing political turmoil and the civil war. Prior to that Sri Lanka has, actually shown a significant deterioration in its relative per capita income, which has not been a common feature for many other countries listed in the Table. Moreover, there is little doubt that inadequate economic performance in Sri Lanka as such is far more crucial among the Asian countries, as it needs to be considered in comparison with the country's unique initial advantageous position.

Table 3

Sri Lanka among Asian Economies: Per capita GNP relative to USA

\begin{tabular}{lrrrrr}
\hline & 1955 & 1960 & 1970 & 1980 & 1995 \\
\hline Sri Lanka & 12.5 & 12.5 & 9.3 & 10.4 & 13.1 \\
India & 6.5 & 7.4 & 6.0 & 5.7 & 8.2 \\
Pakistan & 6.2 & 6.8 & 8.1 & 7.3 & 7.8 \\
Indonesia & $\ldots$ & 5.8 & 4.8 & 8.4 & 13.2 \\
Thailand & 7.4 & 9.6 & 11.9 & 14.3 & 27.0 \\
Malaysia & 14.2 & 15.0 & 15.8 & 25.8 & 37.8 \\
Hong Kong & $\ldots$ & 21.0 & 32.6 & 55.1 & 98.5 \\
South Korea & 8.9 & 8.7 & 12.8 & 19.8 & 48.9 \\
Singapore & $\ldots$ & 16.6 & 24.2 & 44.3 & 85.4 \\
Taiwan & $\ldots$ & 13.8 & 21.3 & 32.9 & 46.7 \\
\hline
\end{tabular}

Note: ... Data not available.

Source: Athukorala (2001), based on the Penn World Tables (world wide web page of the Natio nal Bureau of Economic Research).

\footnotetext{
${ }^{8}$ Malaysia's higher per capita income can also be attributed to its small population and large plantation sector, compared to Sri Lanka.
} 


\section{Policy and political swings}

The long-term slow growth of the Sri Lankan economy has been attributed largely to the frequent policy and political swings during the post independence development history of the country, as the changes in policy regimes were closely linked to the changes in the political arena. ${ }^{9}$ The regular general elections often resulted in shift in power between two major political parties, i.e. the United National Party (UNP) and the Sri Lanka Freedom Party (SLFP). The UNP, which was founded in 1946, is known to be a centre-right political party, of which the ideological position has been based on leissez-faire doctrine. However, it had added elements of social democracy to its leissez-faire thinking of governance. The SLFP emerged in 1953 as a centre-left party by constituting the main alternative to the UNP. In addition to the social democratic orientation of the SLFP, its political and economic thinking had been influenced to a great extent by the socialist ideology. For the same reason, many socialist political parties, which could not form their own governments, also found a room in the coalition governments formed by the SLFP. The minor political parties, based on socialist ideologies and ethnic interests, as well as semi-political organizations and pressure groups also influenced the decision-making process of any government to a great extent. The ruling parties, which were due to face regular general elections, had to maintain an uneasy balance between their short-term political objectives and the country's long-term growth objectives. Yet, mainly due to the ideological discrepancies between the UNP and the SLFP, changes in governments between the two parties following regular general elections have produced parallel shifts in development policy.

After the first general elections in $1947,{ }^{10}$ the UNP remained in power until 1956, having been re-elected in 1952. During the UNP regime of 1947-56 Sri Lanka maintained an open-market economy. However, the criticisms leveled against this policy regime were centred on the issue that it appeared little different from the colonial regime. The government did not envisage a radical change in the classical colonial economic structure, based on the fortune of plantation export crops, and ignored the important role of

\footnotetext{
9 Among a large body of literature on the issue, for example, see Abeyratne (2000), Athukorala and Jayasuriya (1994), Athukorala and Rajapathirana (2000), Bruton (1992), Cuthbertson and Athukorala (1991), Kelegama (2000), Lakshman (1997) and Snodgrass (1999).

${ }^{10}$ Although Sri Lanka gained independence on February 4, 1948, the first national government of the postindependence period was elected in 1947.
} 
industrialization in economic growth with its emphasis on agricultural development. As Snodgrass (1999: 94) wrote it, when the UNP was swept from office in 1956, per capita GNP of the country was not very different from what it was in 1948.

For about two decades after the general elections in 1956, four governments of party coalitions headed by either the SLFP (1956-59, 1960-65, and 1970-77) or the UNP (1965-70) ruled the country. This period was seen as basically an import substitution regime, in which the governments involved in tightening controls on import trade and foreign exchange payments in the face of aggravating foreign exchange crisis as well as expanding the role of the state in the economy. Although the UNP government, elected in 1965, initiated a program of partial liberalization, it also adhered to the prevalent import substitution policy framework of the country. Following this interlude, the subsequent period of 1970-77 witnessed an intensification of state intervention and import substitution under the coalition government of the SLFP and the left wing socialist parties. As it was declared in the budget speech in 1970, this development strategy had an added element of government's commitment to achieve a 'socialist society'. The mass opposition to the economic hardship that people had to undergo during this period had a bearing impact at the general elections in 1977 , which resulted in a massive defeat to all the parties in the coalition government.

The economic slow down during the restrictive import substitution regime that prevalent until 1977 has been extensively studied. ${ }^{11}$ At initial stages, the protectionist move of the country appeared as a response to the growing balance of payments crisis rather than an attempt for import substitution industrialization. However, the intensification of protection since the early 1970s was intended to guide import substitution industrialization. The resource allocation in industry, which was guided by the protective measures, was in favour of capitalintensive and inefficient production lines. They contributed to a high domestic resource cost of production and played a little role in generating employment.

The restrictive trade regime resulted in a virtual shrink of the private sector in the face of growing role of the state, not only as the regulator of the market, but also the main 'entrepreneur' and the main 'supplier' in the economy. The small domestic market as well

${ }^{11}$ For example, see Athukorala and Jayasuriya (1994), Bruton (1992), Cuthbertson and Athukorala (1991) and, Lakshman (1979, 1997). 
as the worsening foreign exchange shortage prevented the expansion of the industrial sector. In addition, various economic controls and nationalization measures effectively hindered private sector expansion. Complicated bureaucratic bottlenecks, rent-seeking activities and political patrona ge characterized the regime. The public sector expanded over industry, agriculture, trade, banking and other key sectors, which were managed by the inefficient state enterprises, of which the losses were compensated by government transfers. The public sector institutions and enterprises, where the employment opportunities were mainly available, became 'job agencies' to provide jobs on political patronage. Consequently, the regime was characterized by stagnant economic growth, which remained on average $2.9 \%$ during the period of 1971-77. It was coupled with little structural changes, rising unemployment, aggravating balance of payments crisis, an acute shortage and rationing of consumer goods and, hence, growing political dissatisfaction. Thus, Sri Lanka, having failed to convert its initial advantageous position into the achievement of subsequent growth momentum, brought its economy to a virtual halt by the mid-1970s.

The UNP, which was elected to power in 1977, quickly initiated radical policy reforms towards a liberalized and export-oriented trade regime and, made attempts to terminate policy and political swings by emulating the East Asian experience. The main elements of policy package such as the liberalization of import trade from high tariffs and quota restrictions, relaxation of control over foreign exchange transactions, elimination of controls over private sector activities, incentives for foreign direct investments and, incentives for export promotion were intended to create an economic environment conducive for rapid economic growth. The policy reforms were also accompanied by political reforms, which were aimed at ensuring the long-term decision making power of an executive presidency by changing the constitution and repressing the dissenting political and semi-political institutions. The economic growth increased rapidly as compared with the pre-1977 period and was maintained at an average rate of around 5\% with a decline in unemployment. But this was achieved in the midst of growing twin civil war in the South as well as in the North in the 1980s, which retarded the potential economic growth of the country. 


\section{Welfare in political competition}

Although the expansion of the welfare system was not supported by the sluggish growth of the economy, in Sri Lanka '...redistributive justice had a strong claim to equal priority with other objectives in economic policy on political, social and humanitarian considerations' (Lakshman 1975: 64-65). The pre- 1977 trade regime has been seen as one with economic policy aimed at more on distribution than growth. It had also been seen as an important strategy of maintaining social peace and containing leftist political influence (Athukorala and Jayasuriya 1994, Dunham and Jayasuriya 2000). To a great extent, the political competition among political parties was instrumental in the initiation as well as the expansion of the welfare system (Alailima 1997). The social agitation against cutbacks in welfare measures was important and decisive in the political competition throughout the post independence history of the country. The subsequent 'politicization' of the system by the political parties for popularity and power was also crucial. Having identified the 'welfare dependency syndrome' of the society, the political parties, with the support of semi-political institutions and other pressure groups in the society, started using the welfare system as a strong weapon in gaining political popularity and attacking the political opponents.

A crucial early lesson that has been learnt by the political parties in this respect was the mass violent protest backed by leftist political parties against the government's attempt to cut back consumer subsidies in 1953. The incident forced the Prime Minister to resign and the government to reverse the action. Since then, the political parties were involved in a competition among themselves by giving promissory notes to expand the welfare measures to gain popularity and power at every general election. Therefore, the competitive and pluralistic political system of the country was instrumental in expanding the welfare state regardless of its very basic foundation-the economic growth.

Sri Lanka has provided an excellent case study for examining, among other things, the debate on the trade-off between growth and equity (Bhalla and Glewwe 1986, Dunham and Jayasuriya 2000, Isenman 1980, Lakshman 1975, 1997). The underlying factors of slow economic growth of the country were associated directly with, not the welfare system, but the elements of the pre-1977 restrictive trade regime. Nevertheless, the extensive welfare system combined with slow growth of the economy created an 
unsustainable contradiction in development. Faced with sluggish growth performance, the state failed to generate resources and opportunities in order to meet the rising social demand of those who were brought up within a 'welfare democracy'. Therefore, the exclusion of individuals as well as social groups from their access to the resources and opportunities was an inevitable outcome of this development contradiction.

\section{Social exclusion and political conflict}

Upward social mobility of people requires an access to the means of social inclusion in terms of resources and opportunities such as income, consumption, employment and education. People who were upgraded in the development process through welfare and exposed to the changing global economic environment improve their capabilities and social aspirations. There is a distinction drawn between the provision of basic needs and the achievement of economic growth as respectively 'direct' and 'indirect' methods of promoting economic development (Bhalla and Glewwe 1986, Snodgrass 1999). Sri Lankan experience clearly shows that there is no viable choice between either side, as both are necessary conditions.

An important component missing in the traditional development thinking is the perceptions developed by individuals or social groups over their own development achievements (Abeyratne 1998). Development theorists have conceptualized and planners have formulated 'what people want' on the basis of a set of predetermined basic needs. But people may perceive 'what they want' in a different context. Development solves some problems, but at the same time creates more problems to be solved by the development itself. For example, if the state succeeds in eliminating illiteracy and malnutrition of a large segment of its society, it is considered to be a development achievement. However, from the societal point of view now people are qualified for achieving higher levels than their present levels since they have improved capabilities and expectations. The strategic development problem faced by developing countries has been the expansion of resources and opportunities to allow people to make use of their capabilities and to meet their expectations. It cannot be limited to the provision of basic needs. 


\section{Redistributive justice in a stagnant economy}

The period from 1950s to the early 1970s was marked by a world economic prosperity although the countries like Sri Lanka failed to exploit its advantage and, experienced a slow pace of economic change. Thus income levels and consumption patterns of people in Sri Lanka changed only a little in comparison to that of the world economy. In the context of achieving redistributive justice in a stagnant economy, people have to share poverty rather than wealth. For the same reason, people have to experience a rapidly growing international inequality-a widening gap between their own society and the outside world.

According to the frequent Consumer Finance Surveys of the Central Bank of Sri Lanka (CBSL), average household income has actually dropped in real terms from the early 1960s to the early 1970s (Abeyratne 1998). This means that the growing international inequality of Sri Lanka has been a result of not only the upward change in the world economy but also the downward change in the domestic economy. In a scenario as such, the policy emphasis on equal distribution makes little sense, as there is so little to distribute. Although the redistributive policies were dominant in the development strategy at the time, there is evidence on growing regional inequality within the country in favour of metropolitan regions and urban areas and, against non-metropolitan and rural areas (Abeyratne 1998). This implies that, while on average the whole society of Sri Lanka was compelled to share poverty, it has also been shared unevenly by the communities in different regions.

\section{Youth: the excluded generation}

The social groups that were the most vulnerable to the repercussions of sharing poverty in the context of a stagnant economy, constituted largely by the youth from the "more depressed' regions who were brought up within the post independence system of 'welfare democracy'. They were large as a proportion of population and, were more educated and healthier than their former generation. They were more politically conscious and exposed more to the repercussions of the development changes outside than their previous generation. With improved human capabilities as a result of the extensive welfare system, this young generation confronted a situation in which they had little role to play and little room to participate in the development process of the country. With escalated social aspirations and expectations as a result of the extensive welfare system, this young 
generation confronted a situation, where there was little capacity to provide means for their upward social mobility.

The unemployment problem in developing countries has become a critical issue with the beginning of the labour flight from, and the depletion of economic activities of, traditional societies. In Sri Lanka this has been a result of the rapid growth of population along with a growing proportion of its youth and the rapid expansion of formal education during the post-independent period. Table 4 shows the expansion of the unemployed population in Sri Lanka by age group as a percentage of total labour force in each age group. The statistics clearly show that the rate of unemployment among young population in the labour force was exceptionally high, and it has increased significantly during 196373. Table 5 shows that this unemployed youth belonged to the more educated groups. When the rate of unemployment is calculated as a percentage of labour force in each educational category, it appears to be low for those who have not received formal school education and for those who have obtained the highest educational qualifications, i.e. university degrees. Unemployment has become a cruc ial problem for those who have obtained school education above secondary levels. In addition, their unemployment rates together with those of university graduates have increased significantly during 1963-73.

\section{Table 4}

\begin{tabular}{lccr}
\multicolumn{4}{c}{ Rate of unemployment by age group (\%) } \\
\hline $\begin{array}{l}\text { Age group } \\
\text { (Years) }\end{array}$ & $\mathbf{1 9 6 3}$ & $\mathbf{1 9 7 3}$ & $\mathbf{1 9 8 6 / 8 7}$ \\
\hline $14-18$ & 47.5 & 65.8 & 48.0 \\
$19-25$ & 30.3 & 47.5 & 35.3 \\
$26-35$ & 7.8 & 15.2 & 10.6 \\
$36-45$ & 2.4 & 3.9 & 3.2 \\
$46-55$ & 2.7 & 1.2 & 0.7 \\
Over 55 & 1.9 & 0.8 & 0.6 \\
Total & 13.8 & 24.0 & 15.5 \\
\hline \multicolumn{4}{l}{} \\
\hline
\end{tabular}

Unemployment problem has been aggravating partly because of the mismatch between aspirations of educated youth and the employment opportunities available in the country. Generally there were employment opportunities available in the country, but these jobs were not of the type aspired by the educated young people who felt that they belonged to higher social strata by education and entitled to 'white-collar' jobs (ILO 1971). The educated youth no longer wished to remain in the traditional economy (Hettige 
1992). With improved aspirations and expectations that have to be satisfied in the context of a modern economy, they entered into the labour force seeking their career development in the modern sectors. It became a critical problem when the modern economy was not expanding enough to absorb the massive flight of educated youth from the traditional economies in the non-metropolitan regions and rural sectors of the country.

Table 5

Rate of unemployment by educational attainment (\%)

\begin{tabular}{lrrr}
\hline Level of education & $\mathbf{1 9 6 3}$ & $\mathbf{1 9 7 3}$ & $\mathbf{1 9 8 6 / 8 7}$ \\
\hline No schooling & 6.1 & 8.0 & 2.9 \\
Completed primary education & 10.5 & 14.1 & 5.0 \\
Completed secondary education $^{\text {Obtained GCE (Ordinary Level) }}{ }^{\mathrm{a}}$ & 23.0 & 37.1 & 19.8 \\
Obtained GCE (Advanced Level) $^{\mathrm{a}}$ & 39.3 & 47.4 & 28.5 \\
Obtained university degree $^{\mathrm{a}}$ & 13.9 & 44.4 & 36.8 \\
\hline
\end{tabular}

a: GCE: General Certificate of Education or equivalent.

Source: CBSL: Consumer Finance Surveys (various issues)

Education was always perceived by the Sri Lankan society as the avenue for upward social mobility. In fact, it was the only avenue for upward social mobility of the majority people, come from lower social strata. The parents of these social strata, who were confined to the socially and economically 'less-rewarding' traditional rural agriculture and other similar activities in the North as well as in the South wished to see their children's upward social mobility through education. The aspirations and expectations resulted from this social perception were met by the spread of free education since independence. Therefore the free education created an increasing flow of educated youth seeking avenues for their inclusion into the modern society (Lakshman 1997: 207).

The lack of opportunities in the modern society not only frustrated the ambitious educated youth but also challenged the privileged position of the existing regions and the existing social groups. Tiny upper strata of both Sinhala and Tamil communities were in a privileged position at the time of independence in terms of social status, income, employment and education due to a number of historical factors (Jupp 1978, Manor 1984, SSA 1985). These upper strata largely came from Colombo in the Western Province and Jaffna in the Northern province, which also resulted in an over-representation of Tamils in employment and higher education. The flow of educated youth from the other provinces of the country, which were considered to be relatively depressed regions, posed an increasing 
challenge to this 'old privileged' social groups. The vast majority of newcomers emerged from neglected social groups and regions of the country during the colonial period. In addition, they became proportionately large due to the population explosion. They represented all ethnic groups, but owing to the ethnic composition of the population, the majority of new comers belonged maturally to the Sinhala community. As normally the 'opportunities' are indivisible, the larger the demand for limited opportunities the greater will be the number of excluded, whatever the measures adopted for their equal distribution.

\section{From political conflict to civil war}

The social exclusion itself would not have triggered civil war. Rather it created fertile ground for the emergence and sustenance of political conflicts, which could lead to an outbreak of collective violence. Increased social exclusion opened up avenues for the formation of frustrated social groups. '...When relatively small groups or categories are incorporated in larger ones, they become more conscious of themselves, and they begin to emphasize an identity of their own they never felt before' (Kloos 1993: 11). Being exposed increasingly to the changes in the outside world, and left out in their own society from the avenues of inclusion, the small social groups perceive their exclusion as well as their right for inclusion and integration, according to their own standards. Therefore, social exclusion of groups from the mainstream process of change, resulting from the contradictions in the development process, forms the groundwork for the emergence of political conflict.

The simmering political tension in Sri Lanka, which had roots deep into the contradictions in the development process of the country, escalated into the twin civil war a few years after the introduction of the liberalized trade regime in 1977. Based on this sequence of events, some analysts have inferred that the civil war in Sri Lanka is mainly a product of trade liberalization, by overlooking the fundamental policy errors throughout the post independence era, which set the groundwork for the civil war. For instance, Gunasinghe (1984) argues that trade liberalization swept away the main agricultural activities in the North, affecting adversely the Tamil farmers and damaging the ethnic relations in the country. Dunham and Jayasuriya (2000) argue that dismantling social welfare and widening inequality in the liberalized trade regime moved the country away 
from social peace and dragged into insurrections: 'Sri Lanka paid high price for its inadequate attention to distributional issues in the course of economic liberalization' (2000: 107). Although there are crucial links of the civil war to the social and political events of the post-1977 period, its attribution to the liberalized trade regime is an oversimplification of the development contradictions that had been intensifying for decades.

It is difficult to support an argument that educated youth, who did not wish to remain in the traditional economies of their former generation, took arms as their parents lost income sources in the traditional economies. Moreover, although there has been a growth of income and expenditure inequality in the post-reform period, it does not mean that 'the poor became poorer when the rich became richer'. With higher growth performance, the generation of employment and income for the rural sector with the expansion of labour-intensive industry has been much greater than that in the pre-1977 stagnant economy, where people were compelled to share poverty. Perhaps trade liberalization in Sri Lanka was too late in a sense that it had inadequate time span to neutralize the fertile ground for political conflict that had already been established. If Sri Lanka initiated its policy reforms earlier-at least by the beginning of the 1970s -in shifting from its 'soft' phase of import substitution regime in the 1960s to a liberalized regime, just like Malaysia, Sri Lanka could have perhaps avoided the potential civil war.

Interestingly, some observers have been impressed by the fact that, unlike most of the other war-stricken countries, Sri Lanka has maintained its gr owth and distributive performance in the midst of a civil war. For instance, Stewart and O'Sullivan (1999: 374) stated that '...unlike most conflict-ridden countries, Sri Lanka has enjoyed sustained economic growth and continued overall improvement in human indicators even while suffering violent conflict on a large scale'. Although there might be a number of reasons for Sri Lanka's outstanding performance, the most critical factor seems to be the trade liberalization reforms commenced before the out break of civil war. If the civil war had erupted prior to 1977 policy reforms, the Sri Lankan experience could not have been an exception.

There is no simple correlation between the contradictions in the development process and the emergence of political conflict. Political conflict indeed has its roots not 
only in economic, but also in social, cultural and political spheres. It is a multi dimensional process of escalation and intensification. Even in the countries with similar patterns of the development process, there is no single pattern of emerging political conflict. This is because the similar patterns of the development process coupled with different cultural, social and political factors could act as either stabilizing or destabilizing forces. In contrast, even if there is a tendency for potential political conflict, a particular pattern of rapid development process could abate such possibilities. Although economic conditions are of prime importance in social exclusion, the frustrated social groups themsekes may stress their identity in terms of social, cultural and political factors. 'Failed economic policies often provide the context of despair and desperation which encourage channeling of frustrations on ethnic lines' (Bardhan 1997: 1386). This is particularly important in the case of Sri Lanka, as the Tamil separatist movement of the country's twin civil war gained momentum and continuity through channeling the frustrated youth on ethnic lines. An outbreak of civil war from political conflict requires the conditions of outbreak, i.e. organization, mobilization, opportunity and leadership. A large pool of frustrated youth that had been accumulated in the historical development process of the country was readily available as the main resource. With the emergence of the necessary conditions in the right time, the country's widespread youth resentment and frustration were exploited and mobilized by dividing into two facets of political conflict.

\section{Concluding remarks}

The purpose of this paper was to contribute to the current debate on the relationship between economic development and political conflict in developing countries through a case study of the 'twin political conflict' in Sri Lanka. In the current debate, economic discrimination and inequality among social groups have received much attention as causes of political conflict and, consequent civil war. Moreover, the overwhelming emphasis on ethnicity as the prime source of political conflict has prevented going beyond mere discriminations and inequalities between ethnic groups in explaining the causes of civil war. The analysis in this paper clearly points to the need for going beyond the popular ethnic dimensions and looking into the limitations and fundamental contradictions in the overall development process in broadening our understanding of the economic roots of civil war. 
Since the 1970s, Sri Lanka experienced a development of political conflict simultaneously in two facets-Tamil separatist movements in the North and the Sinhala youth uprising in the South- and their escalation into the stage of large scale civil war in the 1980s. Sri Lanka's political issue has largely been reduced into an 'ethnic conflict' by focussing only on one facet of the conflict. However, an important feature of the issue is the historical development of conflict between as well as within communities, sharing a common ground and ultimately giving birth to the country's twin civil war.

The overall political conflict in Sri Lanka has its roots in the contradictions in the country's historical development process, resulted from policy errors. On the basis of its initial advantageous position at the time of independence, Sri Lanka developed itself as an exceptional case of a welfare state in the third world, which was also influenced by the political competition in its multi-party democratic political model. The people emerging out of the welfare system constituted a large proportion of the population due to the then population explosion and consisted of educated youth from all com munities in the entirety of Sri Lanka. They had improved human capabilities and high social expectations and, hence, created an increasing social demand for resources and opportunities in the economy.

Rapid economic growth was needed to sustain the welfare state as well as to meet the massive social demand created by it. As the economy failed to convert its initial advantageous position into a sustained rapid growth, the new comers who were brought up within a system of 'welfare democracy' had to face the scarcity of resources and opportunities of the types they aspired as means and ends of satisfying their needs. This contradiction in the development process resulted in social exclusion of individuals and social groups from the mainstream development process. Widespread social exclusion, though not a sufficient condition for the eruption of civil war, created a fertile ground for the emergence and sustenance of political conflict. With the emergence of necessary conditions in the right time, this fertile ground for political conflict was exploited for and the frustrated youth was mobilized into the twin political conflict of Sri Lanka. As a mobilization device, the ethnic factor was important in gaining momentum and continuity in one facet of the conflict. 
The strategic development problem faced by developing countries is not limited only to the provision of basic needs to its population. It is only one manifestation of the broader challenge of generating resources and opportunities to make use of human capabilities and to satisfy social expectations. Attempts to achieve redistributive justice in a stagnant economy is bound to fail sooner or later as it forces people to share poverty rather than wealth and to live through the sense of exclusion and frustration. The Sri Lankan experience suggests that there is no possible choice between the provision of basic needs and the achievement of economic growth as alternatives of promoting human development, as it raises serious problems of sustainability of the deve lopment process, economically as well as politically.

\section{References}

Abeyratne, S. (2000) 'Policy and Political Issues of Economic Growth of Sri Lanka' in S.T. Hettige and M. Mayer (eds.) Sri Lanka at Crossroads: Dilemmas and Prospects after 50 Years of Independence, New Delhi, Macmillan

Abeyratne, S. (1998) Economic Change and Political Conflict in Developing Countries with Special Reference to Sri Lanka, Amsterdam, VU University Press

Abeysekera, C. and Gunasinghe, N. (eds.), (1987) Facets of Ethnicity in Sri Lanka, Colombo, Social Scientists' Association of Sri Lanka

Alailima, P.J. (1997) 'Social Policy in Sri Lanka' in W.D. Lakshman, (ed.) Dilemmas of Development: Fifty years of Economic Change in Sri Lanka, Colombo, Sri Lanka Association of Economists

Arunatilake, N., Jayasuriya, S. and Kelegama, S. (2001) 'The Economic Cost of the War in Sri Lanka', World Development, 29(9): 1483-1500

Athukorala, P. (2001), Employment Intensive Development: The Malaysian Experience, (mimeo), Geneva, International Labour Office

Athukorala, P. and Jayasuriya, S. (1994) Macroeconomic Policies, Crisis, and Growth in Sri Lanka, 1969-90, Washington, DC, World Bank

Athukorala, P. and Rajapathirana, S. (2000) Liberalization and Industrial Transformation: Sri Lanka in International Perspective, Oxford, Oxford University Press

Bardhan, P. (1997) 'Method in the Madness? A PoliticalEconomy Analysis of the Ethnic Conflicts in Less Developed Countries', World Development, 25(9): 1381-1398

Bhalla, S. S. (1988) 'Is Sri Lanka an Exception? A Comparative Study of Living Standard' in T.N Srinivasan and P.K. Bardhan (eds.) Rural Poverty in South Asia, New York, Columbia University Press 
Bhalla, S.S. and Glewwe, P. (1986) 'Growth and Equity in Developing Countries: A

Reinterpretation of the Sri Lankan Experience', World Bank Economic Review, 1(1): 35-63

Bruton, H.J. (1992) The Political Economy of Poverty, Equity and Growth: Sri Lanka and Malaysia, New York, Oxford University Press

CBSL (2000) Annual Report 2000, Colombo, Central Bank of Sri Lanka

CBSL (various issues) Consumer Finance Surveys of Sri Lanka, Colombo, Central Bank of Sri Lanka

Collier, P. (2001) 'Implications of Ethnic Diversity', Economic Policy, 16(32): 129-155

Collier, P and Hoeffler, A. (1998) 'On Economic Causes of Civil War', Oxford Economic Papers, 50:563-573

Cuthbertson, A.G. and Athukorala, P. (1991) 'Sri Lanka' in D. Papageorgiou, M. Michaely and A.M. Choksi (eds.) Liberalizing Foreign Trade: The Experience of Indonesia, Pakistan and Sri Lanka, Cambridge, Basil Blackwell

Dunham, D. and Jayasuriya, S. (2000) 'Equity, Growth and Insurrection: Liberalization and the Welfare Debate in Contemporary Sri Lanka', Oxford Development Studies, 28(1): 97-110

Easterly, W. and Levine, R. (1997) 'Africa's Growth Tragedy: Policies and Ethnic Divisions', Quarterly Journal of Economics, 112(4): 1203-1250

Gunasinghe, N. (1984) 'Open Economy and Its Impact on Ethnic Relations in Sri Lanka', Lanka Guardian, Issues of January 7, 14 and 21

Gurr, T.D. (1993) Minorities at Risk: A Global View of Ethnopolitical Conflicts Washington DC, Institute of Peace Press

Hettige, S. (ed.), (1992) Unrest or Revolt: Some Aspect of Youth Unrest in Sri Lanka, Colombo, Goethe-Institut

Hicks, J.R. (1959) 'Reflections on the Economic Problems of Ceylon', in Papers by Visiting Economists Colombo, Planning Secretariat, 9-21

ILO (1971) Matching Employment Opportunities and Expectations: A Programme of Action for Ceylon, Geneva, International Labour Office

Isenman, P. (1980) 'Basic Needs: The Case of Sri Lanka', World Development, 8(3): 237-258

Jayawardena, K. (1984) 'Class Formation and Communalism', Race and Class, 26(1): 52-62

Jupp, J. (1978) Sri Lanka: Third World Democracy, London, Fank Cass Co. Ltd.

Kearney, R.W. (1973) The Politics ofCeylon (Sri Lanka) London, Cornell University Press.

Kelegama, S. (2000) 'Development in Independent Sri Lanka: What Went Wrong?' Economic and Political Weekly, 35(17): 1477-1490

Kloos, P. (1993) 'Globalization and Localized Violence’, Folk, 35: 5-16 
Lakshman, W.D. (ed.), (1997) Dilemmas of Development: Fifty years of Economic Change in Sri Lanka, Colombo, Sri Lanka Association of Economists

Lakshman, W.D. (ed.), (1979) Public Enterprises in the Economic Development of Sri Lanka, Colombo, National Institute of Business Management

Lakshman, W.D. (1975) 'Economic Growth and Redistributive Justice as Policy Goals: A Study of Recent Experience of Sri Lanka', Modern Ceylon Studies, 6(1): 64-87

Lewis, W.A. (1985) Racial Conflict and Economic Development, Cam bridge, Harvard University Press

Manor, J. (ed.), (1984) Sri Lanka in Change and Crisis, London, Croom Helm

Moore, M. (1993) 'Thoroughly Modern Revolutionaries: The JVP in Sri Lanka', Modern Asian Studies, 27(3): 593-642

Obeyesekere, G. (1974) 'Some Comments on the Social Backgrounds of the April 1971 Insuregency in Sri Lanka (Ceylon)', Journal of Asian Studies, 33(3): 367-384

Oliver, H.M. Jr. (1957) Economic Opinion and Policy in Ceylon, Durham, Duke University Press

Richardson, J.M. Jr. and Samarasinghe, S.W.R. de A. (1991) 'Measuring the Economic Dimensions of Sri Lanka's Ethnic Conflict' in S.W.R. de A. Samarasinghe and R. Coughlan (eds.) Economic Dimensions of Ethnic Conflict, London, Printer Publishers

Robinson, J. (1959) 'Economic Possibilities of Ceylon', in Papers by Visiting Economists, Colombo, Planning Secretariat

Rule, J.B. (1988) Theories of Civil Violence, Berkeley, University of California Press

Sen, A. (1988) 'Sri Lanka's Achievements: How and When', in T.N. Srinivasan and P.K. Bardhan (eds.) Rural Poverty in South Asia, New York, Columbia University Press

Sen, A. (1983) 'Development: Which Way Now?', Economic Journal, 93: 745-762

Snodgrass, D.R. (1999) 'The Economic Development of Sri Lanka: A Tale of Missed Opportunities', in R.I. Rotberg (ed.) Creating Peace in Sri Lanka: Civil War and Reconciliation, Washington DC, Brookings Institution Press

Snodgrass, D.R. (1966) Ceylon: An Export Economy in Transition, Illinois, Richard D. Irwin, Inc.

Spencer, J. (ed.) (1990) Sri Lanka: History and the Roots of the Conflict, London, Routledge

SSA (1985) Ethnicity and Social Change in Sri Lanka, Colombo, Social Scientists' Association (SSA) of Sri Lanka

Stewart, F. (2000) 'Crisis Prevention: Tackling Horizontal Inequalities', Oxford Development Studies, 28(3): 245-262

Stewart, F., FitzGerald, V. and Associates (2001) War and Underdevelopment, Volume I, The Economic and Social Consequences of Conflict, Oxford, Oxford University Press 
Stewart, F. and O'Sullivan, M. (1999) 'Democracy, Conflict and Development - Three Cases' in G. Ranis, S.C. Hu and Y.P. Chu (eds.) The Political Economy of Comparative Development into the $21^{\text {st }}$ Century, Cheltonham, Edward Elgar

Tambiah, S.J. (1986) Sri Lanka: Ethnic Fratricide and the Dismantling of Democracy, London, I.B. Tauris \& Co.

UNDP (annual issues) Human Development Report, United Nations Development Programme, New York, Oxford University Press

Wilson, A.J. (1988) The Break-up of Sri Lanka: The Sinhalese-Tamil Conflict, Honolulu: University of Hawaii Press

Wilson, A.J. (1979) Politics in Sri Lanka, 1947-1979, London, Macmillan

World Bank (annual issues) World Development Report, Washington DC, World Bank 